\title{
Silencing of URG11 expression inhibits the proliferation and epithelial-mesenchymal transition in benign prostatic hyperplasia cells via the RhoA/ROCK1 pathway
}

\author{
GUANYING ZHANG $^{1}$, FENG ZHU ${ }^{2}$, GUANGYE HAN ${ }^{1}$, ZEYU LI ${ }^{1}$, \\ QUANFENG YU ${ }^{1}$, ZHENHUI LI ${ }^{1}$ and JIANCHANG LI ${ }^{1}$ \\ ${ }^{1}$ Second Department of Urinary Surgery; ${ }^{2}$ First Department of Urinary Surgery, \\ First Affiliated Hospital of Xinxiang Medical University, Weihui, Henan 453100, P.R. China
}

Received September 13, 2017; Accepted February 9, 2018

DOI: $10.3892 / \mathrm{mmr} .2018 .8993$

\begin{abstract}
Upregulated gene 11 (URG11) represents a gene upregulated by hepatitis B virus X protein and is involved in the biological processes of multifarious tumors. The present study aimed to investigate the protective effects and regulatory mechanisms of URG11 in benign prostatic hyperplasia (BPH). URG11, Ras homolog family member A (RhoA) and Rho-associated protein kinase 1 (ROCK1) expression was detected in patients with $\mathrm{BPH}$ using reverse transcription-quantitative polymerase chain reaction (RT-qPCR). Furthermore, URG11 expression was silenced using URG11-targeting small interfering RNAs. In addition, cell viability was determined by performing a Cell Counting Kit-8 assay, and the effect of URG11 on the cell cycle was investigated by flow cytometry. Expression levels of cyclin D1, p27, E-cadherin, N-cadherin, vimentin, RhoA and ROCK1 were investigated by RT-qPCR and western blotting. The results revealed that the expression levels of URG11, RhoA and ROCK1 were enhanced in patients with BPH-1 cells compared with matched healthy controls. Furthermore, it was demonstrated that transforming growth factor $\beta$ (TGF- $\beta$ ) induced the proliferation of BPH-1 cells in vitro, and silencing of URG11 inhibited the effects of TGF- $\beta$ on BPH- 1 cell proliferation and the cell cycle. In addition, silencing of URG11 altered the expression levels of cell cycle-associated genes, epithelial-mesenchymal transition-associated genes, and RhoA and ROCK1 protein levels. Thus, the results of the present study suggest that URG11 may be a potential therapeutic target, which may be important to
\end{abstract}

Correspondence to: Dr Jianchang Li, Second Department of Urinary Surgery, First Affiliated Hospital of Xinxiang Medical University, 88 Jiankang Road, Weihui, Henan 453100, P.R. China E-mail: jianchanglii@163.com

Key words: upregulated gene 11, prostatic hyperplasia, epithelial-mesenchymal transition, Ras homolog family member A, Rho-associated protein kinase 1 inhibit the development and progression of prostatic hyperplasia.

\section{Introduction}

Benign prostatic hyperplasia (BPH) has become a common and frequently-occurring disease among elderly men worldwide, following the improvements in living standards and the prolongation of average life expectancies (1). Age, growth and testicular function have previously been revealed to affect the pathogenesis of BPH (2); however, its underlying mechanisms remain unclear. In recent years, the role of upregulated gene 11 (URG11; also termed von Willebrand factor C and EGF domain-containing protein) in the pathogenesis of BPH has gained increasing attention.

URG11 was initially identified as an upregulated gene in hepatitis B virus $\mathrm{X}$ protein ( $\mathrm{HBX}$ )-positive $\mathrm{HepG} 2$ cells by polymerase chain reaction (PCR)-selected cDNA subtraction, and it has also been demonstrated that URG11 promotes the growth of hepatocellular carcinoma and tumorigenesis (3). URG11 encodes for a $70 \mathrm{kDa}$ protein, which comprises of cysteine-rich and lectin domains (4). A further study revealed that lectin domains are closely associated with cell adhesion, matrix interaction, migration and invasion (5). Furthermore, it has previously been demonstrated that the expression of URG11 is enhanced in liver, thyroid, gastric and bladder cancer $(3,4)$. In addition, a previous study revealed that URG11 is involved in the regulatory processes of cell growth, adhesion, migration and tumor metastasis (6). Furthermore, it has been demonstrated that URG11 is involved in epithelial-mesenchymal transition (EMT) via E-cadherin in the human proximal tubule cells (7). Therefore, URG11 may be an important gene in the progress of tumorigenesis and metastasis. However, the function and mechanism of URG11 in the pathogenesis and development of BPH have not yet been determined.

EMT refers to the transformation process whereby epithelial cells lose their polarity and move freely among the cell matrix with a mesenchymal cell phenotype (8). A previous study has demonstrated that within the patients with BPH, epithelial cells lose E-cadherin protein expression, get vimentin protein expression, which suggests that the development 
of BPH may be initiated from the dysregulation of prostate epithelial cells (9). Transforming growth factor- $\beta$ (TGF- $\beta$ ) is a pleiotropic cytokine that is involved in cell reconstruction processes, such as cell proliferation, apoptosis, differentiation, migration and invasion (10). TGF- $\beta$ is considered to have an important role in EMT (11). Despite the TGF- $\beta$ signaling pathway being relatively simple, its regulatory mechanism is highly complex. Currently, the TGF- $\beta$ signaling pathway and its associations with other signaling pathways has become an important research field.

The Ras protein family of guanosine triphosphates (GTPases) is comprised of numerous subfamilies. Ras family proteins include Rho, Rac1 and Cdc42 (12). Rho acts as a molecular switch in response to cytokines, G-protein coupled receptors, adhesion molecules and growth factor cell surface receptors by cycling between active GTP and inactive guanine diphosphate (13). Rho-associated protein kinase (ROCK)1 and ROCK2 protein kinases of the Rho protein family (14) that regulate actomyosin contractility via phosphorylation of the myosin light chain and inactivation of the myosin-binding subunit of myosin phosphatase (15). Furthermore, Ras homolog family member A (RhoA) and downstream target ROCK1 are involved in numerous biological and pathological processes, including cell adherence, apoptosis, proliferation and migration (16).

In the present study, the expression levels of URG11, RhoA and ROCK1 in patients with BPH, the effect of TGF- $\beta$ on $\mathrm{BPH}-1$ cells, and the roles of URG11 in BPH-1 cell proliferation, the cell cycle and EMT were investigated. In addition, the role of URG11 in BPH was investigated. The results of the present study suggest that URG11 may be a novel therapeutic target for the treatment of BPH.

\section{Materials and methods}

Clinical samples. A total of $5 \mathrm{ml}$ of peripheral blood from 37 male patients (aged from 40-75 years old; mean, $52.3 \pm 3.6)$ with prostatic hyperplasia and the healthy prostate glands were collected from healthy volunteers (aged from 40-75 years old; mean, 49.9 \pm 5.2 ) at The First Affiliated Hospital of Xinxiang Medical University (Xinxiang, China) between July 2015 and June 2016. The participants who were diagnosed as BPH and willing to participate in the present study were enrolled. The exclusion criteria were as follows: Prostate carcinoma, bladder cancer, urethral stricture; cardiovascular, liver, kidney and hematopoietic disease and mental illness. Serums were separated by centrifugation $(1,200 \mathrm{x} \mathrm{g}$, $\left.10 \mathrm{~min}, 4^{\circ} \mathrm{C}\right) 2 \mathrm{~h}$ following collection, and the supernatant serum was then frozen at $-80^{\circ} \mathrm{C}$ until further analysis. The present study was approved by the Ethics Committee of The First Affiliated Hospital of Xinxiang Medical University, and written informed consent was obtained from all participants. No patients had undergone radiotherapy or chemotherapy prior to surgical resection.

Cell culture. Human BPH-1 cells (BPH epithelium) and normal prostate gland cells (RWPE-1) were obtained from the American Type Culture Collection (Manassas, VA, USA). Cells were cultured in RPMI-1640 medium (Invitrogen; Thermo Fisher Scientific, Inc., Waltham, MA,
USA) with $10 \%$ fetal bovine serum (FBS; Hyclone; GE Healthcare Life Sciences, Logan, UT, USA), 100 U/ml penicillin and $100 \mathrm{mg} / \mathrm{ml}$ streptomycin (Invitrogen; Thermo Fisher Scientific, Inc.) in a humidified atmosphere at $37^{\circ} \mathrm{C}$ and $5 \% \mathrm{CO}_{2}$. Cell morphology was then observed under a microscope (magnification, $\mathrm{x} 40$ ).

TGF- $\beta$ treatment. BPH- 1 cells $\left(5 \times 10^{4}\right.$ cells/well) were seeded into 6 -well plates with $2 \mathrm{ml}$ serum-free medium and then incubated at $37^{\circ} \mathrm{C}$ for $8 \mathrm{~h}$. Following this, cells were treated with $10 \mathrm{ng} / \mathrm{ml} \mathrm{TGF}-\beta$ for $24 \mathrm{~h}$.

Small interfering (si)RNA interference. Negative control siRNA (si-NC) and URG11 siRNA (si-URG11) were purchased from Shanghai GenePharma Co., Ltd. (Shanghai, China). The sequence of si-NC was 5'-UUCUCCGAACGUGUCACG U-3', and the sequence of si-URG11 was 5'-CAGACGGAU UGCUGUACUU-3'. BPH-1 cells $\left(2 \times 10^{4}\right.$ cells/well $)$ were seeded into 6-well plates and incubated at $37^{\circ} \mathrm{C}$ overnight. Following this, cells were transfected with si-NC $(50 \mu \mathrm{M})$ and si-URG11 $(50 \mu \mathrm{M})$ using Lipofectamine ${ }^{\circledR} 3000$ (Invitrogen; Thermo Fisher Scientific, Inc.) according to the manufacturer's protocol. After $36 \mathrm{~h}$ post-transfection, the cells were collected to proceed with the subsequent experiments.

RNA extraction and reverse transcription-quantitative $P C R$ $(R T-q P C R)$. Total RNA was extracted from the treated BPH-1 cells using the TRIzol reagent (Invitrogen; Thermo Fisher Scientific, Inc.). cDNA was synthesized from the extracted RNA using a reverse transcription kit, PrimeScript RT reagent kit (Takara Bio, Inc., Otsu, Japan) according to manufacturer's instructions. The reaction mixture was incubated at $37^{\circ} \mathrm{C}, 15 \mathrm{~min}$, and reaction was inactivated at $85^{\circ} \mathrm{C}$ for $5 \mathrm{sec}$. Following this, qPCR was performed using SYBR Premix Ex Taq $^{\text {TM }}$ (Takara Bio, Inc.). The PCR thermocycling conditions were as follows: $95^{\circ} \mathrm{C}$ for $10 \mathrm{~min}, 35$ cycles at $95^{\circ} \mathrm{C}$ for $15 \mathrm{sec}$ and $60^{\circ} \mathrm{C}$ for $60 \mathrm{sec}$. Expression levels were quantified using the $2^{-\Delta \Delta \mathrm{Cq}}$ method (17). The primer sequences are presented in Table I.

Western blotting. Cells were rinsed with PBS (cat. no. 37350; Stemcell Technologies, Inc., Beijing, China) and directly lysed in ice-cold radioimmunoprecipitation assay buffer (Beijing Solarbio Science \& Technology, Beijing, China). Protein samples $(20 \mathrm{mg}$ ) were then separated by performing $10 \%$ SDS-PAGE and then transferred onto polyvinylidene difluoride membranes. Membranes were then blocked with 5\% bovine serum albumin (Sigma-Aldrich; Merck KGaA, Darmstadt, Germany; cat. no. A0281) at room temperature. After $2 \mathrm{~h}$, membranes were then incubated with the following primary antibodies (all Abcam, Cambridge, UK) at $4^{\circ} \mathrm{C}$ overnight: Anti-URG11 [1:600 (3)], anti-cyclin D1 (1:10,000; cat. no. ab134175), anti-cyclin-dependent kinase inhibitor 1B (p27; 1:5,000; cat. no. ab32034), anti-E-cadherin (1:50; cat. no. ab1416), anti-N-cadherin (1:500; cat. no. ab18203), anti-vimentin (1:800; cat. no. ab8978), anti-RhoA (1:5,000; cat. no. ab187027), anti-ROCK1 (cat. no. ab45171, 1:200), anti-prostate specific antigen (PSA; 1:5,000; cat. no. ab182031) and anti-GAPDH (1:5,000; cat. no. ab8245). Following this, the membranes were incubated with an 
Table I. Primer sequences used in reverse transcription-quantitative polymerase chain reaction assay.

Gene Primers sequence

URG11 Forward: 5'-GCCCTTAGTCCAATGTTGTC-3'

PSA Reverse: 5'-TGCCCTCTGGACAGGAGGCT-3' Forward:5'-AGGGTACGGTATGGGGTGTA-3' Reverse: 5'-TCATCCTCCCACTTCGAACC-3'

RhoA Forward: 5'-ACCAGTTCCCAGAGGTTTA TGT-3'

Reverse: 5'-TTTGGT CTTTGCTGAACACT-3'

ROCK1 Forward: 5'-ACCTGTAACCCAAGGAGAT GTG-3'

Reverse: 5'-CACAATTGGCAGGAAAG

Cyclin D1 Forward: 5'-GAACAAACAGATCATCCG CAA-3'

Reverse: 5'-CCCTTCTGGTATCAAAATGC-3'

p27 Forward: 5'-AACGTGCGAGTGTCTAA CGG-3'

Reverse: 5'-CCCTCTAGGGGTTTGTGAT' TCT-3

E-cadherin Forward: 5'-CGGACGATGATGTGAAC ACC-3'

Reverse: 5'-TTGCTGTTGTGCTTAACCCC-3'

N-cadherin Forward: 5'-CATCCCTCCAATCAACTTGC-3' Reverse: 5'-ATGTGCCCTCAAATGAAACC-3'

Vimentin Forward: 5'-GAGTCCACTGAGTACCG GAG-3'

Reverse: 5'-ACGAGCCATTTCCTCCTTCA-3' GAPDH Forward: 5'-ATGTCGTGGAGTCTACTGGC-3' Reverse: 5'-TGACCTTGCCCACAGCCTTG-3'

URG11, upregulated gene 11; PSA, prostate specific antigen; RhoA, Ras homolog family member A; ROCK1, Rho-associated protein kinase 1; p27, cyclin-dependent kinase inhibitor 1B.

appropriate horseradish peroxidase-coupled secondary antibody at room temperature for 2 h (1:5,000; cat. no. ab6721, Abcam). Proteins were visualized on membranes using an enhanced chemiluminescent kit (Pierce; Thermo Fisher Scientific, Inc.) on the ODYSSEY Infrared Imaging System (LI-COR Biosciences, Lincoln, NE, USA). The data was then analyzed using Quantity One software version 4.6. (Bio-Rad Laboratories, Inc., Hercules, CA, USA). Protein expression levels were normalized to GAPDH.

Cell Counting Kit-8 (CCK-8) assay. Cells (2.5x104/ml) were collected with complete medium and seeded into 96-well plates in a $200 \mu \mathrm{l}$ cell suspension. Following the transfection of cells according to the aforementioned protocol, CCK-8 reagent (Beyotime Institute of Biotechnology, Haimen, China; $15 \mu \mathrm{l} /$ well) was added to the wells and incubated for $3 \mathrm{~h}$ at $37^{\circ} \mathrm{C}$ with $5 \% \mathrm{CO}_{2}$. At days $1,2,3,4$ and 5 post-transfection, absorbance was then determined at $450 \mathrm{~nm}$ using an Elx800 Reader (Bio-Tek Instruments, Inc., Winooski, VT, USA).
Cell cycle assay. Treated cells were washed with PBS and then fixed with $70 \%$ ethanol for $30 \mathrm{~min}$ on ice. Following this, RNA was degraded with $20 \mathrm{mg} / \mathrm{ml}$ RNase (Sigma-Aldrich; Merck $\mathrm{KGaA}$ ) for $1 \mathrm{~h}$ at $37^{\circ} \mathrm{C}$. Cells were then labeled with $20 \mathrm{mg} / \mathrm{ml}$ propidium iodide (Sigma-Aldrich; Merck KGaA). Cell cycle images were obtained and analyzed using the FACSCalibur (BD Biosciences, Franklin Lakes, NJ, USA) flow cytometer and FlowJo software version 6.2.1 (FlowJo LLC, Ashland, OR, USA).

Statistical analysis. For statistical analyses between two groups, the Student's t-test was performed. For multiple comparisons, one-way analysis of variance followed by Turkey's post hoc test was performed. All statistical analyses were performed using IBM SPSS Statistics version 21 (IBM Corp., Armonk, NY, USA) software, and all data are presented as the mean \pm standard deviation. $\mathrm{P}<0.05$ was considered to indicate a statistically significant difference.

\section{Results}

URG11, RhoA and ROCK1 are highly expressed in patients with $\mathrm{BPH}$. The results of the present study revealed that URG11 expression was markedly higher in serum from patients with prostatic hyperplasia compared with in the healthy controls $(\mathrm{n}=37$; $\mathrm{P}=0.0013$; Fig. 1A). The expression of RhoA was also significantly upregulated in the serum of patients with $\mathrm{BPH}$ compared with the controls $(n=37 ; \mathrm{P}=0.0073$; Fig. 1B). In addition, ROCK1 expression was also significantly increased in the serum of patients with prostatic hyperplasia compared with healthy controls $(n=37 ; P=0.0011$; Fig. $1 C)$. The relative expression levels of URG11, RhoA and ROCK1 were presented in Fig. 1D.

URG11 expression is silenced in BPH-1 cells. BPH-1 cells were cultured in RPMI-1640 medium with $10 \%$ FBS at $37^{\circ} \mathrm{C}$ for $48 \mathrm{~h}$ and then observed under a light microscope. Cells grew adhering to the wall of the culture dish, exhibited rectangular or irregular polygon shapes, had large and round nuclei, and grew in close contact and irregular arrangements. These characteristics demonstrated that the cells exhibited typical epithelial cell morphology (Fig. 2A). To further investigate this, the expression levels of PSA in cells were determined. The results demonstrated that the expression level of PSA was significantly enhanced in BPH-1 cells compared with normal prostate gland cells (Fig. 2B and C). Thus, it was confirmed that the obtained cells were BPH-1 cells. Furthermore, the expression level of URG11 in normal prostate gland cells and BPH-1 cells was investigated. The results revealed that the expression levels of URG11 were significantly enhanced in BHP-1 cells compared with normal prostate gland cells (Fig. 2B and C). To further investigate the potential roles of URG11 on BPH-1 cell proliferation and migration, BPH-1 cells were either treated with PBS (control), or transfected with si-NC or si-URG11. RT-qPCR and western blot assays were used to detect the expression level of URG11. The results demonstrated that URG11 expression was significantly suppressed in BPH-1 cells transfected with si-URG11 compared with the si-NC group (Fig. 2D and E; $\mathrm{P}<0.001$ ). These results revealed that the efficiency and specificity of URG11 knockdown were high. 
A
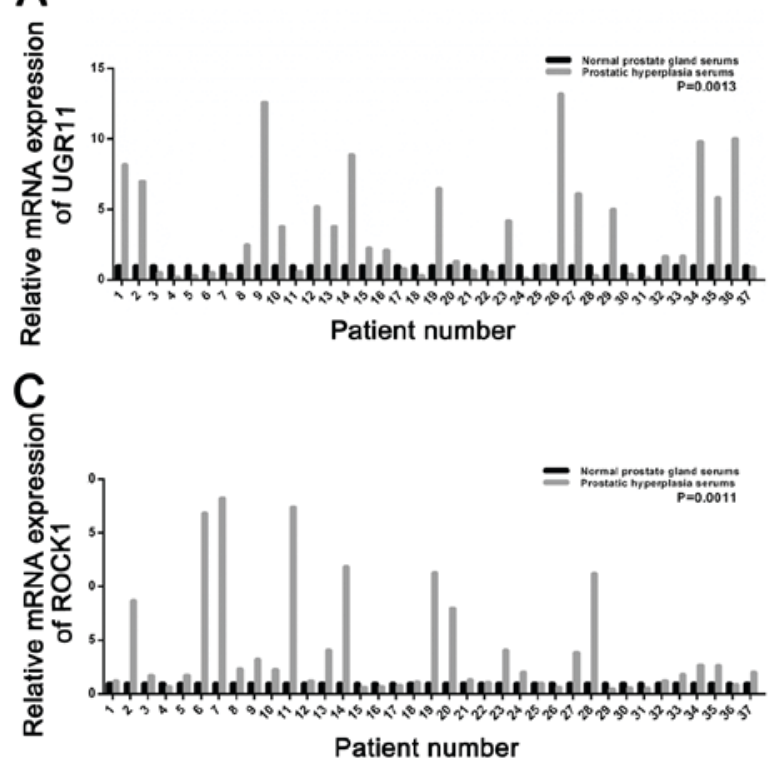

B

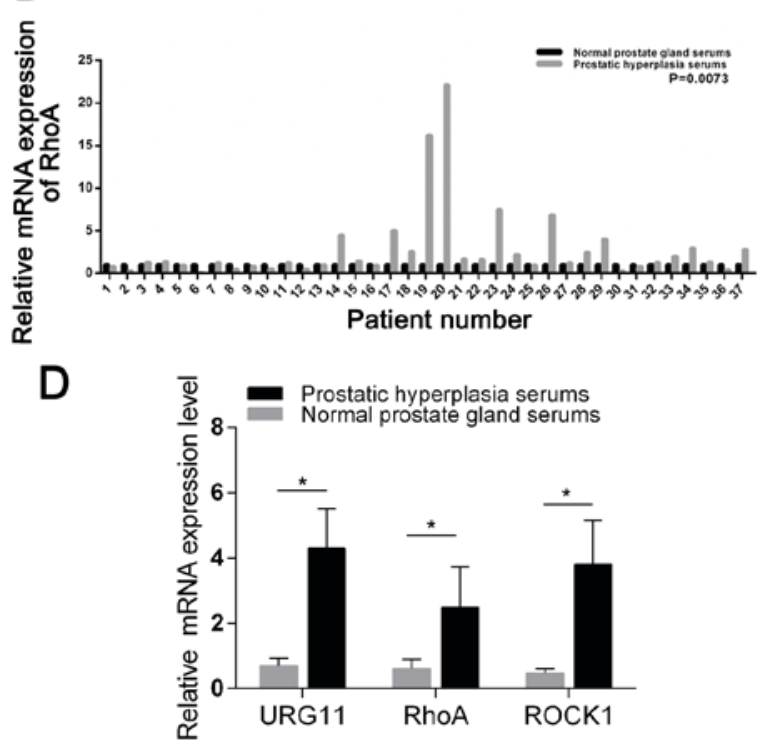

Figure 1. URG11, RhoA and ROCK1 are highly expressed in patients with prostatic hyperplasia. (A-D) URG11, RhoA and ROCK1 expression levels were investigated via RT-qPCR assays using the serum of patients with prostatic hyperplasia ( $\mathrm{n}=37$ ) and associated normal prostate gland. $\mathrm{P}=0.0013$ for URG11 expression, $\mathrm{P}=0.0073$ for RhoA expression and $\mathrm{P}=0.0011$ for ROCK1 expression ( $\mathrm{n}=3$ ). URG11, upregulated gene 11; RhoA, Ras homolog family member A; ROCK1, Rho-associated protein kinase 1; RT-qPCR, reverse transcription-quantitative polymerase chain reaction.
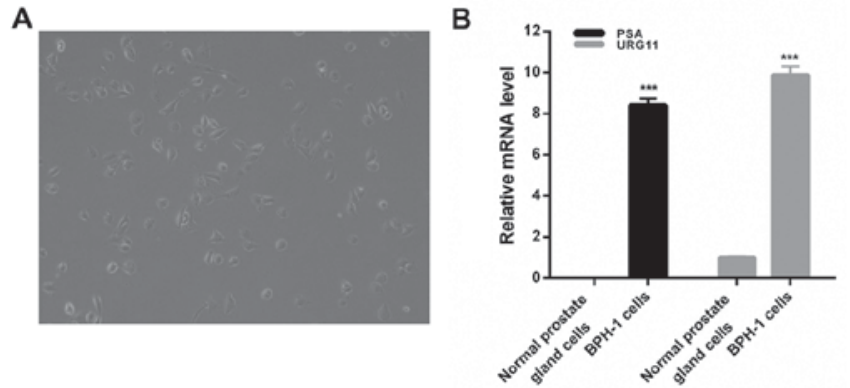

D

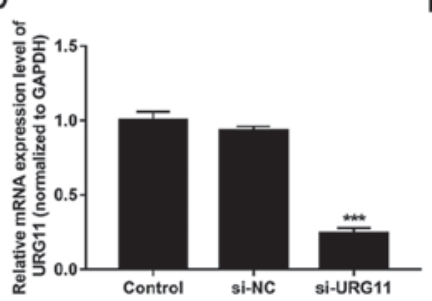

E
C
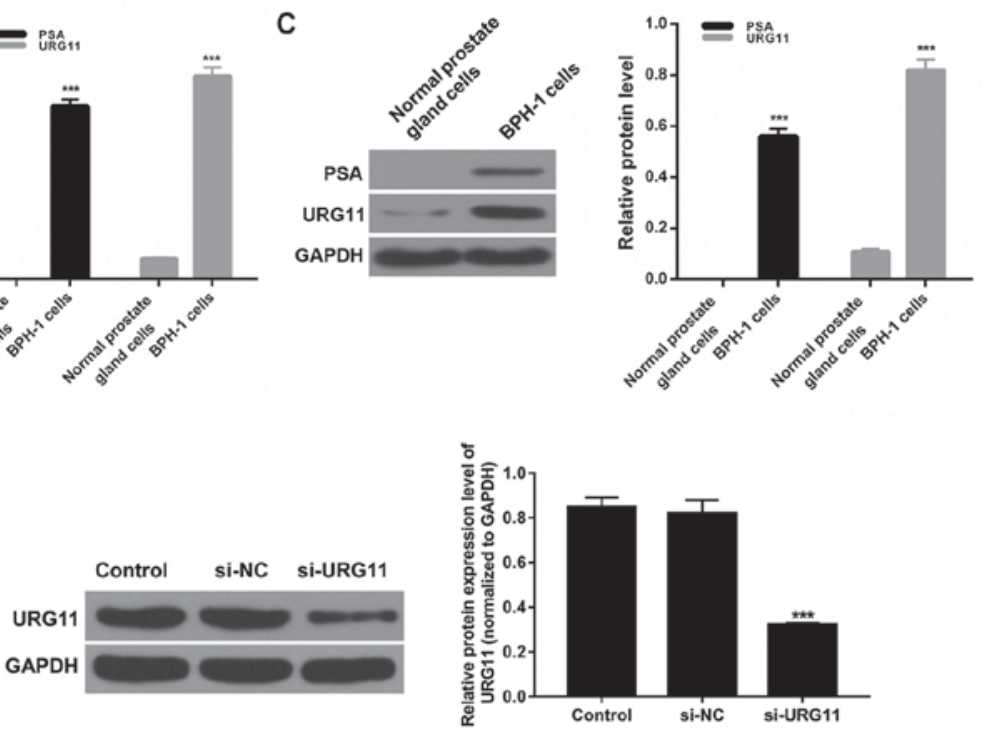

Figure 2. URG11 expression is suppressed in BPH-1 cells. (A) The morphology of BPH-1 cells was investigated using a light microscope. Magnification, $\mathrm{x} 100$; scale bar, $100 \mu \mathrm{m}, \mathrm{n}=3$. (B) RT-qPCR was performed to determine the expression level of URG11 in normal prostate gland cells and BPH-1 cells ( $\mathrm{n}=4$ ). (C) Western blot assays were performed to determine the expression levels of PSA and URG11 in normal prostate gland cells and BPH-1 cells (n=3). ${ }^{* * *} \mathrm{P}<0.001$ vs. normal prostate gland cells. (D) BPH-1 cells were transfected with PBS, si-NC and si-URG11. mRNA expression levels of URG11 were determined using RT-qPCR assays $(n=4)$. (E) Protein expression level of URG11 was investigated using western blot assays, and GAPDH was used as control for normalization $(\mathrm{n}=3) .{ }^{* * *} \mathrm{P}<0.001$ vs. si-NC. PSA, prostate specific antigen; URG11, upregulated gene 11; BPH, prostatic hyperplasia; RT-qPCR, reverse transcription-quantitative polymerase chain reaction; si, small interfering RNA; NC, negative control.

Decreased expression of URG11 suppresses proliferation and induces cell cycle arrest of BPH-1 cells, regulated by TGF- $\beta$. Previous studies have demonstrated that TGF- $\beta$ enhances cancer progression by inducing EMT (18). To investigate this further, BPH-1 cells were treated with either PBS (control) or TGF- $\beta$ ( $5 \mathrm{ng} / \mathrm{ml}$ for $8 \mathrm{~h}$ ), or transfected with si-NC or si-URG11 and treated with TGF- $\beta$. RT-qPCR analyses revealed that treatment with TGF- $\beta$ significantly enhanced URG11 expression, and that transfection with si-URG11 significantly reversed this increase induced by TGF- $\beta$ (Fig. 3A; $\mathrm{P}<0.001$ ). The CCK- 8 assay results demonstrated that TGF- $\beta$ significantly increased the proliferation of BPH-1 cells, and transfection with si-URG11 significantly suppressed BPH-1 cell proliferation induced by TGF- $\beta$ (Fig. $3 \mathrm{~B}$; $\mathrm{P}<0.01$ or $\mathrm{P}<0.001$ ). In addition, the potential mechanism underlying TGF- $\beta$ and URG11-mediated changes in BPH-1 cell proliferation was 


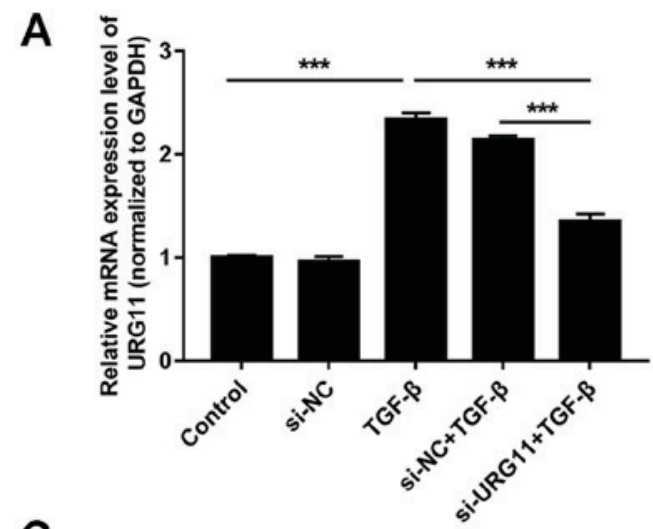

B
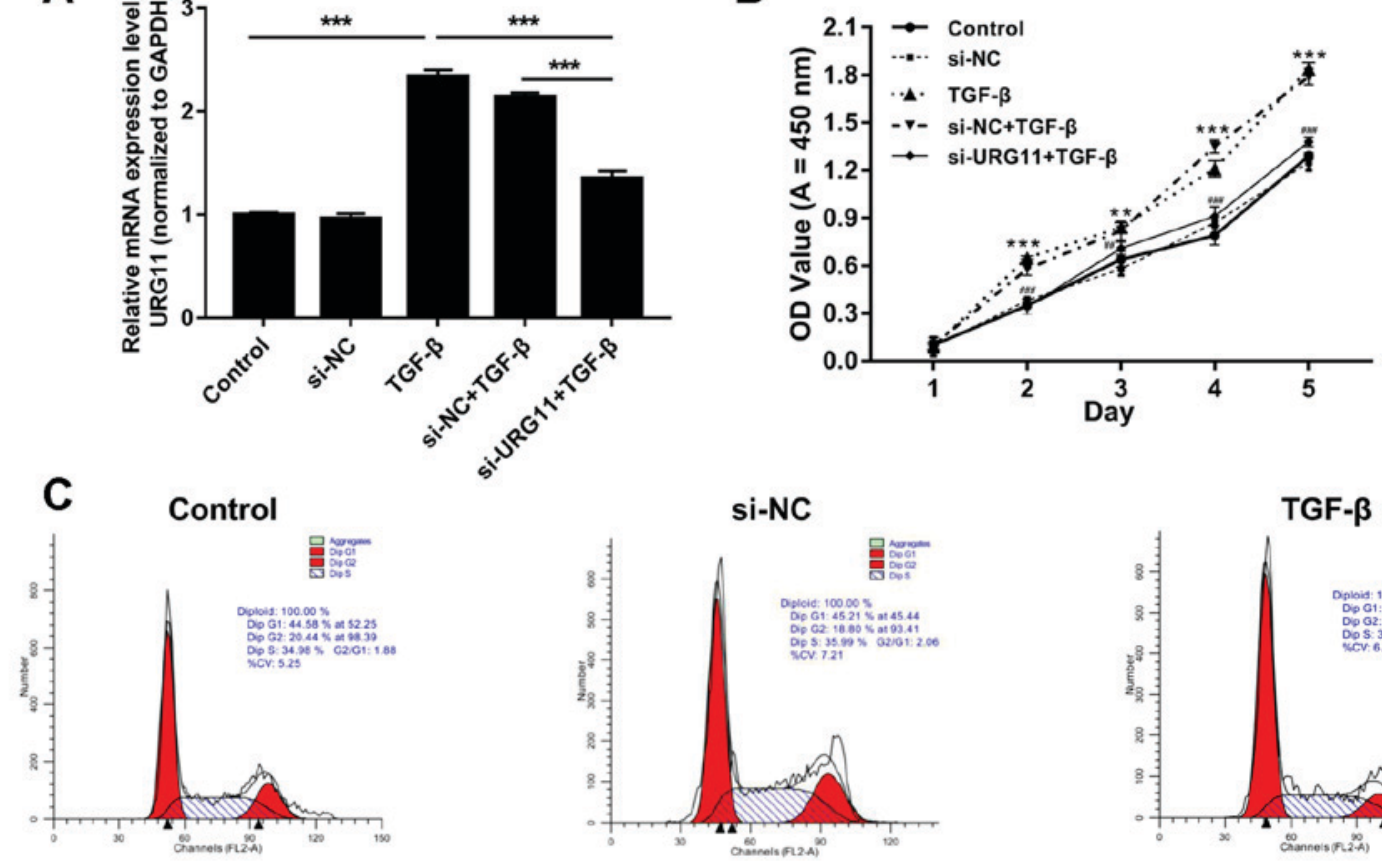

\section{si-NC+TGF- $\beta$}

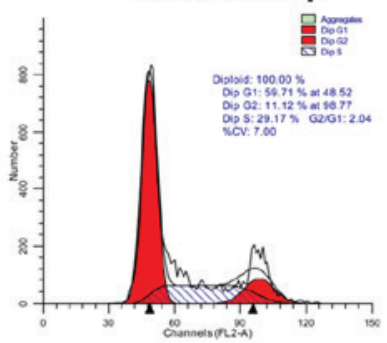

Si-URG11+TGF- $\beta$

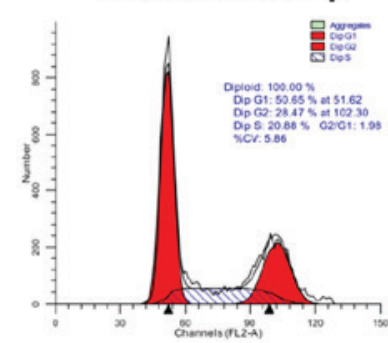

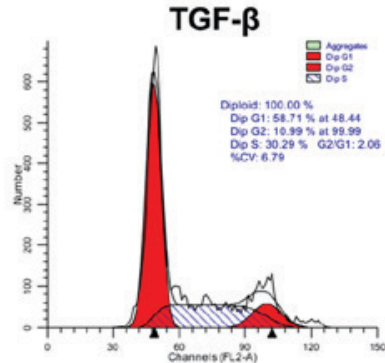

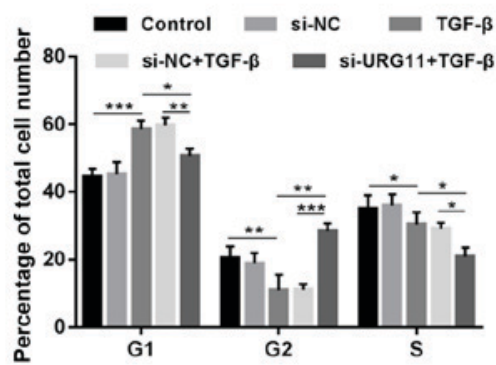

Figure 3. Silencing of URG11 suppresses proliferation and induced cell cycle arrest of BPH-1 cells mediated by TGF- $\beta$. BPH-1 cells were transfected with PBS (control), si-NC, TGF- $\beta$, si-NC plus TGF- $\beta$, and si-URG11 plus TGF- $\beta$, respectively. (A) Reverse transcription-quantitative polymerase chain reaction assays were performed to investigate URG11 expression $\left({ }^{* * * *} \mathrm{P}<0.001, \mathrm{n}=4\right)$. (B) Cell Counting Kit-8 assays were performed to investigate BPH-1 cell proliferation. $\left({ }^{* *} \mathrm{P}<0.01,{ }^{* * * *} \mathrm{P}<0.001\right.$ vs. control group; ${ }^{* \#} \mathrm{P}<0.01$ and ${ }^{\# \# \#} \mathrm{P}<0.001$, si-URG11 + TGF- $\beta$ vs. si-NC + TGF- $\left.\beta, \mathrm{n}=5\right)$. (C) Flow cytometry was performed to investigate cell-cycle distribution. ${ }^{*} \mathrm{P}<0.05,{ }^{* *} \mathrm{P}<0.01,{ }^{* * *} \mathrm{P}<0.001$ ( $\left.\mathrm{n}=4\right)$. URG11, upregulated gene 11 ; si, small interfering RNA; NC, negative control; TGF- $\beta$, transforming growth factor- $\beta$; OD, optical density. All the experiments were independently repeated at least for 3 times.

further investigated using flow cytometry. The results revealed that the proportion of cells in the G1 phase was significantly increased in the TGF- $\beta$ group compared with the control group, and was significantly decreased in si-URG11 + TGF- $\beta$ group compared with the si-NC + TGF- $\beta$ group. The proportion of cells in the G2 phase was decreased in the TGF- $\beta$ group compared with control group, and was significantly increased in the si-URG11 + TGF- $\beta$ group compared with the si-NC + TGF- $\beta$ group (Fig. $3 \mathrm{C} ; \mathrm{P}<0.05, \mathrm{P}<0.01$ or $\mathrm{P}<0.001$ ), suggesting that the downregulation of URG11 promoted the cell cycle arrest.

Silencing of URG11 downregulates the TGF- $\beta$-induced expression levels of cyclin D1, $N$-cadherin and vimentin, and upregulates the expression levels of p27 and E-cadherin. According to the aforementioned results, silencing of URG11 induced cell cycle arrest. The effect of URG11 on cyclin D1 and p27 expression was investigated further, as these proteins are associated with the cell cycle, and it was revealed that TGF- $\beta$ enhanced cyclin D1 expression and suppressed p27 expression; however, transfection with si-URG11 reversed these effects in BPH-1 cells (Fig. 4; $\mathrm{P}<0.01$ or $\mathrm{P}<0.001$ ). In addition, the effect of URG11 on N-cadherin, vimentin and E-cadherin expression levels was investigated, as these proteins are associated with EMT, and it was revealed that treatment with TGF- $\beta$ enhanced the expression levels of $\mathrm{N}$-cadherin and vimentin, and decreased the expression level of E-cadherin (Fig. 4; $\mathrm{P}<0.01$ or $\mathrm{P}<0.001)$. Suppression of URG11 expression via transfection with si-URG11 significantly reversed these effects on BPH-1 cells (Fig. 4; $\mathrm{P}<0.01$ or $\mathrm{P}<0.001$ ).

Suppression of URG11 expression decreases TGF- $\beta$-induced RhoA and ROCK1 expression levels. Studies revealed that RhoA and ROCK1 are downstream targets of TGF- $\beta$ signaling and are involved in cell proliferation, migration and apoptosis processes (19-22). In the present study, it was revealed that RhoA and ROCK1 expression levels were significantly increased by TGF- $\beta$ compared with the control group, and 

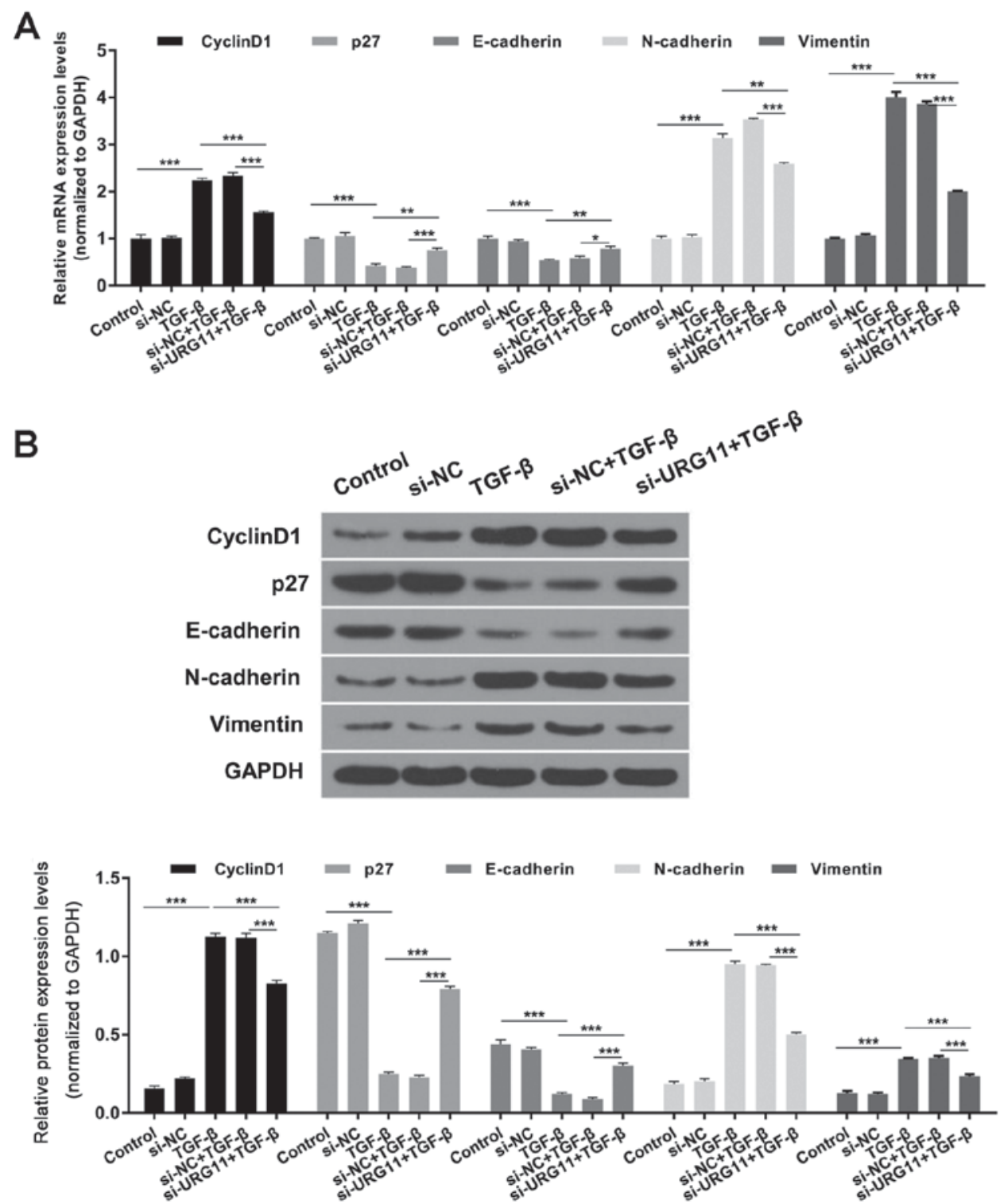

Figure 4. Silencing of URG11 expression decreases cyclin D1, N-cadherin and vimentin expression levels, and enhances p27 and E-cadherin expression levels, regulated by TGF- $\beta$. (A) mRNA expression levels of cyclin D1, p27, E-cadherin, N-cadherin and vimentin were investigated by reverse transcription-quantitative polymerase chain reaction. (B) Protein expression levels of cyclin D1, p27, E-cadherin, $\mathrm{N}$-cadherin and vimentin were determined by western blot assays. ${ }^{*} \mathrm{P}<0.05,{ }^{* *} \mathrm{P}<0.01$ and ${ }^{* * *} \mathrm{P}<0.001$. p27, cyclin-dependent kinase inhibitor $1 \mathrm{~B}$; si, small interfering RNA; NC, negative control; TGF- $\beta$, transforming growth factor- $\beta$; URG11, upregulated gene 11.

significantly decreased in the si-URG11 + TGF- $\beta$ group compared with the si-NC + TGF- $\beta$ group (Fig. $5 ; \mathrm{P}<0.01$ or $\mathrm{P}<0.001)$.

\section{Discussion}

BPH is one of the most prevalent diseases of the urinary system that affects elderly men. The major clinical manifestations of BPH include frequent urination, urgent urination and dysuria (23). Currently, population aging is a major public health problem, particularly in China. With the aging population, the incidence of BPH is expected to increase further and thus seriously affect the quality of life of older men, and may even result in the emergence of serious complications $(24,25)$.

URG11 is an HBX-upregulated gene and regulates HBx-mediated hepatocarcinoma development (26). A previous study demonstrated that silencing of URG11 expression suppresses gastric cancer cell proliferation, adhesion, invasion and metastasis abilities, and prevents cell transition from $\mathrm{G} 1$ phase to $\mathrm{S}$ phase in vitro (6). Furthermore, previous studies have revealed that knockdown of URG11 suppresses lung cancer proliferation and invasion via $\beta$-catenin (27) and induces EMT via E-cadherin and $\beta$-catenin; and overexpression of URG11 enhances hepatocellular carcinoma growth (4). These results suggest that URG11 may regulate tumor progression via regulation of EMT and the $\beta$-catenin signaling pathway. However, the function and underlying mechanisms of URG11 in BPH have not yet been determined. In the present study, it was revealed that the expression of URG11 was significantly enhanced in patients with BPH compared with matched controls, and that decreased URG11 expression suppressed BPH-1 cell proliferation and induced 
A

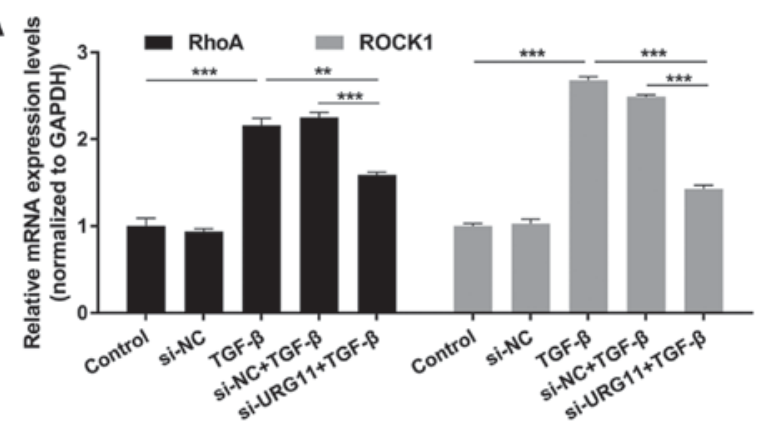

B
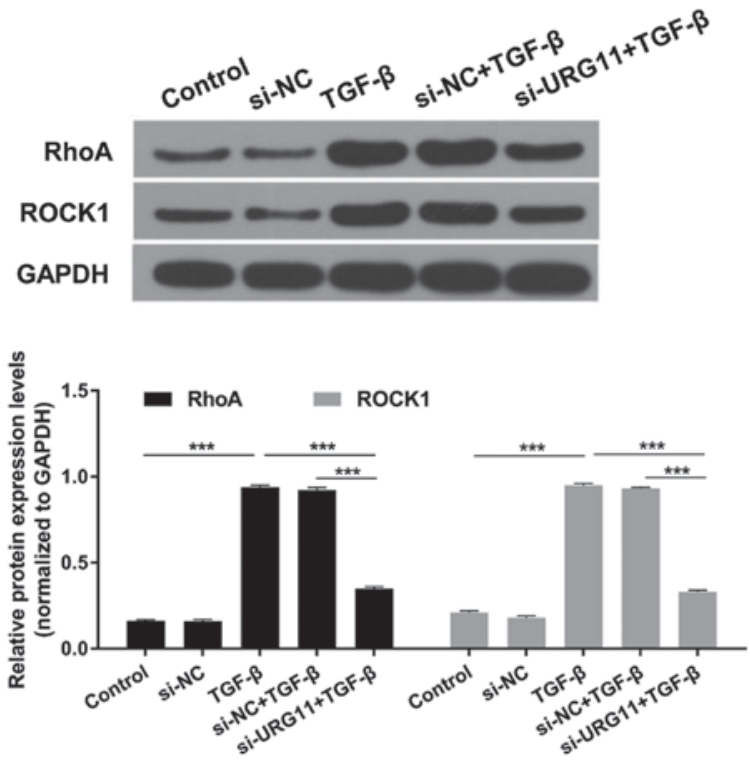

Figure 5. Silencing of URG11 expression decreases RhoA and ROCK1 expression levels regulated by TGF- $\beta$. (A) mRNA expression levels of RhoA and ROCK1 were determined by reverse transcription-quantitative polymerase chain reaction assays. (B) Protein expression levels of RhoA and ROCK1 were determined by western blot assays. ${ }^{* * *} \mathrm{P}<0.01,{ }^{* * * *} \mathrm{P}<0.001$. RhoA, Ras homolog family member A; ROCK1, Rho-associated protein kinase 1; si, small interfering RNA; NC, negative control; TGF- $\beta$, transforming growth factor- $\beta$; URG11, upregulated gene 11.

cycle arrest via regulation of cyclin D1 and p27 expression levels.

EMT is an essential early step and a critical process in tumor metastasis (28). During EMT, tumor cells lose their epithelial characteristics, including cell-cell adhesion and polarity, and obtain mesenchymal-like phenotypes (29). Furthermore, phenotypic markers commonly change during EMT, for example, the epithelial cell phenotypic marker E-cadherin is downregulated and mesenchymal cell phenotypic markers, $\mathrm{N}$-cadherin and vimentin, are upregulated post-EMT (30). Previous studies have demonstrated that URG11 is associated with E-cadherin expression $(31,32)$. E-cadherin, an epithelial cell adhesion protein, is important for the formation and maintenance of embryonic epithelial cells (33). In addition, E-cadherin is important for the maintenance of structural integrity and cell polarity (34). In the present study, it was demonstrated that suppression of URG11 expression significantly enhances E-cadherin expression, and significantly suppresses the expression of $\mathrm{N}$-cadherin and vimentin. TGF- $\beta$ is a multifunctional protein of the TGF- $\beta$ protein superfamily and regulates the growth, differentiation, apoptosis and immunity of numerous cell types (35). Previous studies have demonstrated that TGF- $\beta$ functions as an inducer of EMT and is closely associated with cancer progression, angiogenesis, pathological staging and prognosis $(18,36)$. Thus, the results suggested that silencing of URG11 suppresses EMT progress in BPH.

Rho proteins have GTPase activity and are involved in cell division and proliferation (37). RhoA, an important member of the Rho family, regulates numerous downstream genes, alters actin structure and morphology and regulates cell proliferation, apoptosis, metastasis and other biological processes (38). A recent study demonstrated that ROCK, an important RhoA regulator, is associated with cell apoptosis, EMT, migration and metastasis (39). In the present study, it was revealed that knockdown of URG11 suppresses TGF- $\beta$-induced RhoA and ROCK1 expression levels, indicating that URG11 regulates $\mathrm{BPH}$ progression via the RhoA/ROCK1 signaling pathway.

In conclusion, the results of the present study revealed that URG11, RhoA and ROCK1 expression levels were enhanced in patients with PBH. Additionally, suppression of URG11 expression inhibited TGF- $\beta$-regulated BPH- 1 cell proliferation and induced cell cycle arrest via the regulation of cell cycle-associated genes (cyclin D1 and p27). Furthermore, URG11 knockdown suppressed TGF- $\beta$-mediated EMT of BPH-1 cells. In addition, silencing of URG11 expression significantly decreased RhoA and ROCK1 expression levels regulated by TGF- $\beta$. Therefore, URG11 may represent a novel prognostic marker and candidate drug target for the treatment of BPH.

\section{Acknowledgements}

Not applicable.

\section{Funding}

No funding was received.

\section{Availability of data and materials}

All data generated or analyzed during this study are included in this published article.

\section{Authors' contributions}

GZ wrote the main manuscript. FZ, GH and ZL performed the experiments. GZ and JL designed the study. QY and ZHL performed data analysis. GZ, FZ and JL contributed to manuscript revisions and all authors reviewed the manuscript.

\section{Ethics approval and consent to participate}

The present study was approved by the Ethics Committee of The First Affiliated Hospital of Xinxiang Medical University (Xinxiang, China), and written informed consent was obtained from all participants.

\section{Consent for publication}

Not applicable. 


\section{Competing interests}

The authors declare that they have no competing interests.

\section{References}

1. Mobley D, Feibus A and Baum N: Benign prostatic hyperplasia and urinary symptoms: Evaluation and treatment. Postgrad Med 127: 301-307, 2015.

2. Corona G, Vignozzi L, Rastrelli G, Lotti F, Cipriani S and Maggi M: Benign prostatic hyperplasia: A new metabolic disease of the aging male and its correlation with sexual dysfunctions. Int J Endocrinol 2014: 329456, 2014.

3. Lian Z, Liu J, Li L, Li X, Clayton M, Wu MC, Wang HY, Arbuthnot P, Kew M, Fan D and Feitelson MA: Enhanced cell survival of Hep3B cells by the hepatitis B x antigen effector, URG11, is associated with upregulation of beta-catenin. Hepatology 43: 415-424, 2006.

4. Xie H and Liu J: Increased expression URG11 in hepatocellular carcinoma tissues promotes the growth of hepatocellular carcinoma cells. Xi Bao Yu Fen Zi Mian Yi Xue Za Zhi 31: 1523-1527, 2015 (In Chinese).

5. Zou X, Li X, Liu J, Lian Z, Fan R, Du R, Xie H, Song J and Fan D: Preparation and characterization of a specific monoclonal antibody against a new gene product: URG11. Hybridoma (Larchmt) 25: 378-381, 2006.

6. Du R, Xia L, Sun S, Lian Z, Zou X, Gao J, Xie H, Fan R, Song J, Li X, et al: URG11 promotes gastric cancer growth and invasion by activation of beta-catenin signalling pathway. J Cell Mol Med 14: 621-635, 2010.

7. Du R, Huang C, Bi Q, Zhai Y, Xia L, Liu J, Sun S and Fan D: URG11 mediates hypoxia-induced epithelial-to-mesenchymal transition by modulation of E-cadherin and beta-catenin. Biochem Biophys Res Commun 391: 135-141, 2010.

8. Lamouille S, Xu J and Derynck R: Molecular mechanisms of epithelial-mesenchymal transition. Nat Rev Mol Cell Biol 15: 178-196, 2014.

9. Shao R, Shi J, Liu H, Shi X, Du X, Klocker H, Lee C, Zhu Y and Zhang J: Epithelial-to-mesenchymal transition and estrogen receptor alpha mediated epithelial dedifferentiation mark the development of benign prostatic hyperplasia. Prostate 74 970-982, 2014.

10. Syed V: TGF- $\beta$ signaling in cancer. J Cell Biochem 117: 1279-1287, 2016.

11. Katsuno Y, Lamouille $S$ and Derynck R: TGF- $\beta$ signaling and epithelial-mesenchymal transition in cancer progression. Curr Opin Oncol 25: 76-84, 2013.

12. Chew TW, Liu XJ, Liu L, Spitsbergen JM, Gong Z and Low BC: Crosstalk of ras and rho: Activation of RhoA abates Kras-induced liver tumorigenesis in transgenic zebrafish models. Oncogene 33 2717-2727, 2014.

13. Bryan BA, Dennstedt E, Mitchell DC, Walshe TE, Noma K, Loureiro R, Saint-Geniez M, Campaigniac JP, Liao JK and D'Amore PA: RhoA/ROCK signaling is essential for multiple aspects of VEGF-mediated angiogenesis. FASEB J 24: 3186-3195, 2010

14. Riou P, Kjær S, Garg R, Purkiss A, George R, Cain RJ, Bineva G, Reymond N, McColl B, Thompson AJ, et al: 14-3-3 proteins interact with a hybrid prenyl-phosphorylation motif to inhibit G proteins. Cell 153: 640-653, 2013.

15. Zhao ZS and Manser E: PAK and other Rho-associated kinases-effectors with surprisingly diverse mechanisms of regulation. Biochem J 386: 201-214, 2005.

16. Chan $\mathrm{CH}$, Lee SW, Li CF, Wang J, Yang WL, Wu CY, Wu J, Nakayama KI, Kang HY, Huang HY, et al: Deciphering the transcriptional complex critical for RhoA gene expression and cancer metastasis. Nat Cell Biol 12: 457-467, 2010.

17. Livak KJ and Schmittgen TD: Analysis of relative gene expression data using real-time quantitative PCR and the 2(-Delta Delta C(T)) method. Methods 25: 402-408, 2001

18. Wendt MK, Tian M and Schiemann WP: Deconstructing the mechanisms and consequences of TGF- $\beta$-induced EMT during cancer progression. Cell Tissue Res 347: 85-101, 2012.
19. Riento K and Ridley AJ: Rocks: Multifunctional kinases in cell behaviour. Nat Rev Mol Cell Biol 4: 446-456, 2003.

20. Hu B, Xu C, Cao P, Tian Y, Zhang Y, Shi C, Xu J, Yuan W and Chen H: TGF- $\beta$ stimulates expression of chondroitin polymerizing factor in nucleus pulposus cells through the Smad3, RhoA/ROCK1 and MAPK signaling pathways. J Cell Biochem 119: 566-579, 2018.

21. Wu ML, Chen CH, Lin YT, Jheng YJ, Ho YC, Yang LT, Chen L, Layne MD and Yet SF: Divergent signaling pathways cooperatively regulate TGF $\beta$ induction of cysteine-rich protein 2 in vascular smooth muscle cells. Cell Commun Signal 12: 22, 2014.

22. Mohamed JS and Boriek AM: Stretch augments TGF-beta1 expression through RhoA/ROCK1/2, PTK, and PI3K in airway smooth muscle cells. Am J Physiol Lung Cell Mol Physiol 299: L413-L424, 2010.

23. Bechis SK, Otsetov AG, Ge R and Olumi AF: Personalized medicine for the management of benign prostatic hyperplasia. J Urol 192: 16-23, 2014.

24. Dong X, Chang ES, Zeng P and Simon MA: Suicide in the global chinese aging population: A review of risk and protective factors, consequences, and interventions. Aging Dis 6: 121-130, 2015.

25. Wang W, Guo Y, Zhang D, Tian Y and Zhang X: The prevalence of benign prostatic hyperplasia in mainland China: Evidence from epidemiological surveys. Sci Rep 5: 13546, 2015.

26. Lian Z, Liu J, Li L, Li X, Tufan NL, Clayton M, Wu MC, Wang HY, Arbuthnot P, Kew M and Feitelson MA: Upregulated expression of a unique gene by hepatitis $\mathrm{B} x$ antigen promotes hepatocellular growth and tumorigenesis. Neoplasia 5: 229-244, 2003.

27. Liu ZL, Wu J, Wang LX, Yang JF, Xiao GM, Sun HP and Chen YJ: Knockdown of upregulated gene 11 (URG11) inhibits proliferation, invasion, and $\beta$-catenin expression in Non-small cell lung cancer cells. Oncol Res 24: 197-204, 2016.

28. Davis FM, Stewart TA, Thompson EW and Monteith GR: Targeting EMT in cancer: Opportunities for pharmacological intervention. Trends Pharmacol Sci 35: 479-488, 2014.

29. Hyun KA, Koo GB, Han H, Sohn J, Choi W, Kim SI, Jung HI and Kim YS: Epithelial-to-mesenchymal transition leads to loss of EpCAM and different physical properties in circulating tumor cells from metastatic breast cancer. Oncotarget 7: 24677-24687, 2016.

30. Nijkamp MM, Span PN, Hoogsteen IJ, van der Kogel AJ, Kaanders JH and Bussink J: Expression of E-cadherin and vimentin correlates with metastasis formation in head and neck squamous cell carcinoma patients. Radiother Oncol 99: 344-348, 2011.

31. Liu J, Lian Z, Han S, Waye MM, Wang H, Wu MC, Wu K, Ding J, Arbuthnot P, Kew M, et al: Downregulation of E-cadherin by hepatitis B virus $\mathrm{X}$ antigen in hepatocellullar carcinoma. Oncogene 25: 1008-1017, 2006.

32. Arzumanyan A, Friedman T, Kotei E, Ng IO, Lian Z and Feitelson MA: Epigenetic repression of E-cadherin expression by hepatitis B virus x Antigen in liver cancer. Oncogene 31: 563-572, 2012

33. Riethmacher D, Brinkmann V and Birchmeier C: A targeted mutation in the mouse E-cadherin gene results in defective preimplantation development. Proc Natl Acad Sci USA 92: 855-859, 1995.

34. Huber MA, Kraut N and Beug H: Molecular requirements for epithelial-mesenchymal transition during tumor progression. Curr Opin Cell Biol 17: 548-558, 2005.

35. Talar B and Czyz M: TGF- $\beta$ signaling pathways in cancers. Postepy Hig Med Dosw (Online) 67: 1008-1017, 2013 (In Polish).

36. Gao J, Zhu Y, Nilsson M and Sundfeldt K: TGF- $\beta$ isoforms induce EMT independent migration of ovarian cancer cells. Cancer Cell Int 14: 72, 2014.

37. Surma M, Wei L and Shi J: Rho kinase as a therapeutic target in cardiovascular disease. Future Cardiol 7: 657-671, 2011.

38. Marjoram RJ, Lessey EC and Burridge K: Regulation of RhoA activity by adhesion molecules and mechanotransduction. Curr Mol Med 14: 199-208, 2014.

39. Lotz-Jenne C, Lüthi U, Ackerknecht S, Lehembre F, Fink T, Stritt M, Wirth M, Pavan S, Bill R, Regenass U, et al: A high-content EMT screen identifies multiple receptor tyrosine kinase inhibitors with activity on TGF $\beta$ receptor. Oncotarget 7: 25983-26002, 2016. 